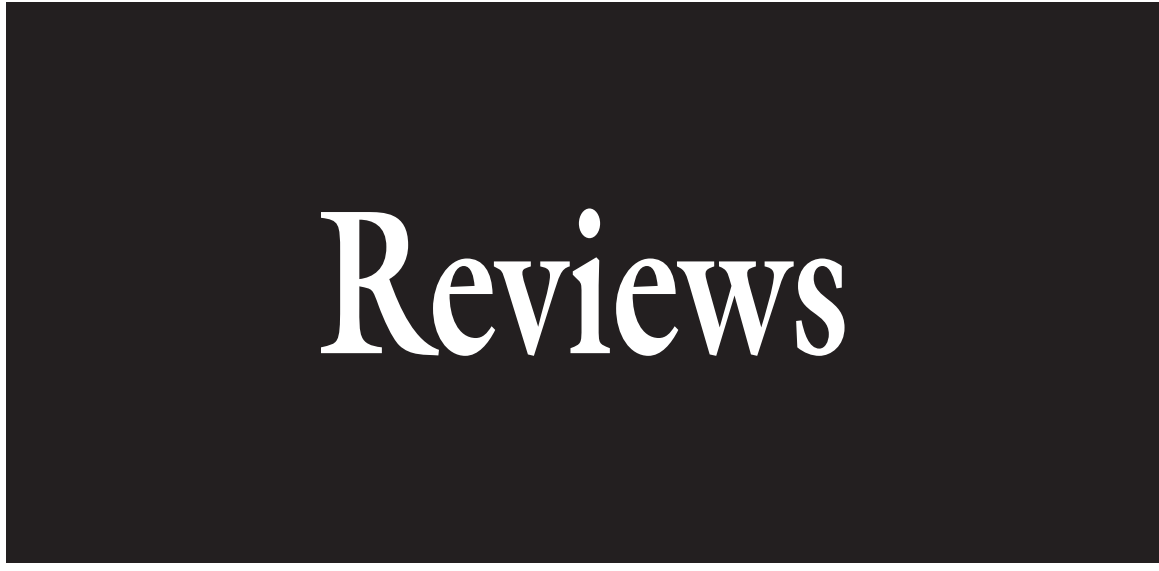

\title{
Opportunities and Challenges to Sustainability in Aquaponic Systems
}

\author{
Richard V. Tyson ${ }^{1,4}$, Danielle D. Treadwell ${ }^{2}$, and Eric H. Simonne ${ }^{3}$
}

ADDITIONAL INDEX WORDs. biofiltration, ammonia, nitrifying bacteria, hydroponic

Summary. Aquaponics combines the hydroponic production of plants and the aquaculture production of fish into a sustainable agriculture system that uses natural biological cycles to supply nitrogen and minimizes the use of nonrenewable resources, thus providing economic benefits that can increase over time. Several production systems and media exist for producing hydroponic crops (bench bed, nutrient film technique, floating raft, rockwool, perlite, and pine bark). Critical management requirements (water quality maintenance and biofilter nitrification) for aquaculture need to be integrated with the hydroponics to successfully manage intensive aquaponic systems. These systems will be discussed with emphasis on improving sustainability through management and integration of the living components [plants and nitrifying bacteria (Nitrosomonas spp. and Nitrobacter spp.)] and the biofilter system. Sustainable opportunities include biological nitrogen production rates of 80 to $90 \mathrm{~g} \cdot \mathrm{m}^{-3}$ per day nitrate nitrogen from trickling biofilters and plant uptake of aquaculture wastewater. This uptake results in improved water and nutrient use efficiency and conservation. Challenges to sustainability center around balancing the aquaponic system environment for the optimum growth of three organisms, maximizing production outputs and minimizing effluent discharges to the environment.

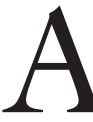

quaponics (Diver and Rinehart, 2010; Nelson, 2007) is an integrated system that links hydroponic production (Jensen, 1997; Resh, 2004) with recirculating aquaculture (Timmons et al., 2002). The advantages of linking crop production and the culture of fish are shared startup, operating, and infrastructure costs; recirculating tank waste nutrient and water removal by plants, thus reducing water usage and waste discharge to the environment; and increased profit

${ }^{1}$ County Extension Director, Orange County Cooperative Extension, Orlando, FL 32812

${ }^{2}$ Assistant Professor, Horticultural Sciences Department, University of Florida, Gainesville, FL 32611

${ }^{3}$ Associate Professor and District Extension Director, University of Florida, Gainesville, FL 32611

${ }^{4}$ Corresponding author. E-mail: rvt@ufl.edu. potential by simultaneously producing two cash crops (Diver and Rinehart, 2010; Rakocy, 1999; Timmons et al., 2002). Properly designed and wellmanaged hydroponic and aquaculture systems may be considered environmentally responsible alternatives to field-grown vegetable production and wild-caught fisheries ( $\mathrm{Lim}$ and
Webster, 2006; Smither-Kopperl and Cantliffe, 2004; Timmons et al., 2002). When these systems are combined, aquaponics closely fits the definition of sustainable agriculture because it combines the production of plants and animals, integrates nutrient flow by natural biological cycles (nitrification), and makes the most efficient use of nonrenewable resources (Gold, 1999).

The potential for plants to use the nutrient by-products of aquaculture and to keep the recirculating water clean has been well documented (Adler et al., 1996, 2000; Lin et al., 2002). The most common aquaponic systems currently in use employ either a mediafilled raised bed, nutrient film technique, or a floating raft system for the plants' growing area integrated with a recirculating aquaculture tank system (Table 1). Recirculating aquaponic systems that produce both fish and plants can accumulate dissolved nutrients from daily feed of fish, which approach concentrations found in hydroponic systems (Rakocy, 1997). The aquaponic nitrogen $(\mathrm{N})$ cycle (Fig. $\mathrm{l}$ ) is of particular interest. Fish produce ammonia $\left(\mathrm{NH}_{3}\right)$, some of which ionizes in water to form ammonium $\left(\mathrm{NH}_{4}^{+}\right)$. Nitrifying bacteria in biofilters convert $\mathrm{NH}_{3}$ to nitrite $\left(\mathrm{NO}_{2}^{-}\right)$and then to nitrate $\left(\mathrm{NO}_{3}^{-}\right)$(Madigan et al., 2003). Plants can absorb $\mathrm{NO}_{3}{ }^{-}$and $\mathrm{NH}_{4}{ }^{+}$. Because $\mathrm{N}$ is the nutrient required in largest amounts by plants and $\mathrm{NO}_{3}{ }^{-}$is often the preferred source (Marschner, 2003), management of these systems to encourage beneficial nitrifying bacteria has the potential to improve system sustainability.

The shortage of fresh water and loss of prime agricultural lands to accommodate growing human populations will require the development of new crops and new agricultural systems to meet the demands for food, fiber, and fuel while reducing the environmental impacts of their production (Fedoroff et al., 2010). The objectives

\begin{tabular}{llll}
\hline $\begin{array}{l}\text { Units } \\
\text { To convert U.S. to SI, } \\
\text { multiply by }\end{array}$ & U.S. unit & SI unit & $\begin{array}{l}\text { To convert SI to U.S., } \\
\text { multiply by }\end{array}$ \\
\hline 3.7854 & $\mathrm{gal}$ & $\mathrm{L}$ & 0.2642 \\
40.7458 & $\mathrm{gal} / \mathrm{ft}^{2}$ & $\mathrm{~L} \cdot \mathrm{m}^{-2}$ & 0.0245 \\
0.4536 & $\mathrm{lb}$ & $\mathrm{kg}$ & 2.2046 \\
28.3495 & $\mathrm{oz}$ & $\mathrm{g}$ & 0.0353 \\
305.1517 & $\mathrm{oz} / \mathrm{ft}^{2}$ & $\mathrm{~g} \cdot \mathrm{m}^{-2}$ & 0.0033 \\
1001.1539 & $\mathrm{oz} / \mathrm{ft}^{3}$ & $\mathrm{~g} \cdot \mathrm{m}^{-3}$ & 0.0010 \\
1 & $\mathrm{ppm}$ & $\mathrm{mg} \cdot \mathrm{L}^{-1}$ & 1 \\
$\left({ }^{\circ} \mathrm{F}-32\right) \div 1.8$ & ${ }^{\circ} \mathrm{F}$ & ${ }^{\circ} \mathrm{C}$ & $\left(1.8 \times{ }^{\circ} \mathrm{C}\right)+32$ \\
& & &
\end{tabular}


Table 1. Selected aquaponic systems mentioned in the literature.

\begin{tabular}{|c|c|c|c|c|}
\hline \multicolumn{2}{|c|}{ Hydroponic } & \multicolumn{2}{|c|}{ Aquaculture } & \multirow[b]{2}{*}{ Literature reference } \\
\hline System & Crop $^{z}$ & System & Crop $^{y}$ & \\
\hline Gravel bed & Tomato & Recirculating tank & Tilapia & Watten and Busch (1984) \\
\hline Sand bed & Tomato & Recirculating tank & Tilapia & McMurtry et al. (1997) \\
\hline Floating raft & Lettuce & Recirculating tank & Tilapia & Rakocy et al. (1997) \\
\hline $\begin{array}{l}\text { Gravel bed, floating } \\
\text { raft, NFT }\end{array}$ & Lettuce & Recirculating tank & Murray cod & Lennard and Leonard (2006) \\
\hline Floating raft, NFT & Lettuce, tomato, pepper & Recirculating tank & Barramundi & Nelson (2007) \\
\hline Perlite bed & Cucumber & Recirculating tank & Tilapia & Tyson et al. (2008a) \\
\hline
\end{tabular}

${ }^{z}$ Tomato (Solanum lycopersicum), bush bean (Phaseolus vulgaris), cucumber (Cucumis sativus), lettuce (Lactuca sativa), basil (Ocimum basilicum), okra (Abelmoschus esculentus), and pepper (Capsicum annumm).

yTilapia (Oreochromis niloticus), trout (Oncorhynchus mykiss), murray cod (Maccullochella peelii peelii), and barramundi (Lates calcarifer).

${ }^{\mathrm{x}}$ Nutrient film technique.

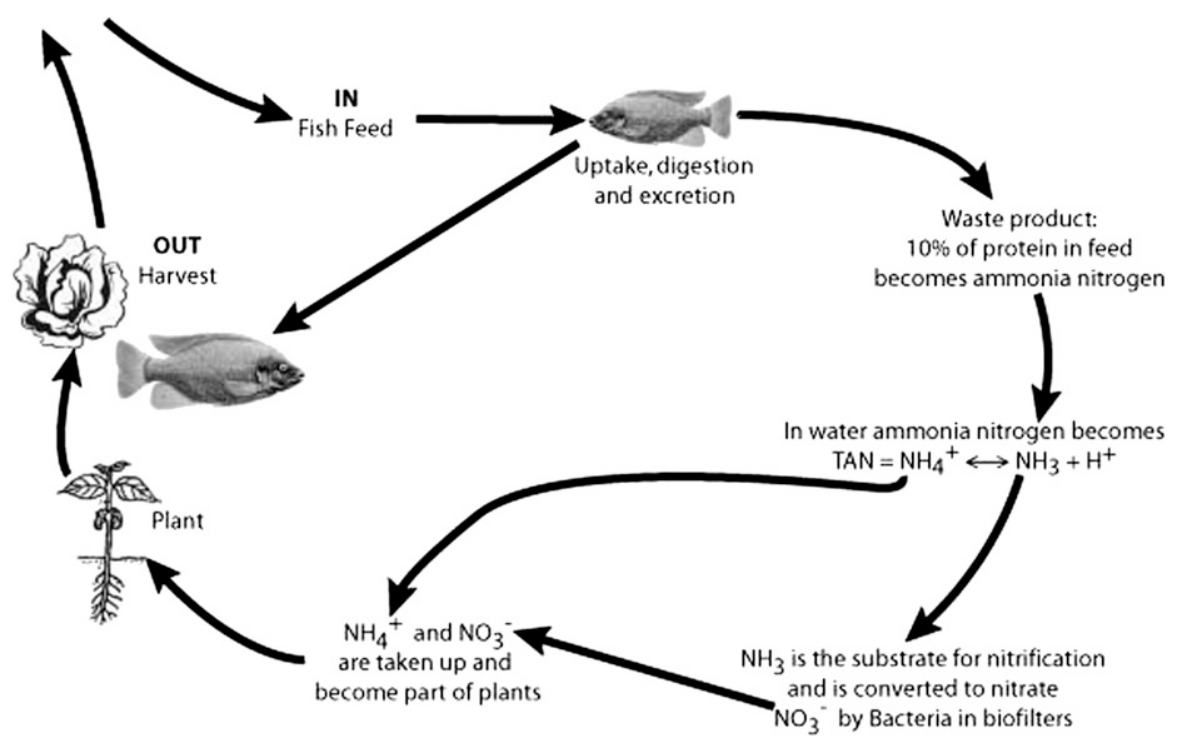

Fig. 1. The nitrogen cycle in aquaponics begins with the introduction of protein in fish feed and its excretion to form total ammonia nitrogen (TAN) in recirculating water. Ammonia $\left(\mathrm{NH}_{3}\right)$ is then converted to nitrate $\left(\mathrm{NO}_{3}{ }^{-}\right)$by nitrifying bacteria (Nitrosomonas spp. and Nitrobacter spp.). Ammonium $\left(\mathrm{NH}_{4}^{+}\right)$ and $\mathrm{NO}_{3}{ }^{-}$are then taken up by plants, and two crops (plants and fish) are harvested from the system; $\mathrm{H}^{+}=$hydrogen ion.

of this study are to identify the opportunities and challenges affecting aquaponic system sustainability and to suggest avenues for future research and demonstration that will increase adoption of this system by the agriculture community.

\section{Sustainability opportunities}

INTEGRATING NUTRIENT FLOWS. Nitrogen budgets for conventional field-grown vegetable crops are often formulated with the knowledge that a portion of these inputs may be lost to the environment through leaching, runoff (Hochmuth, 2000; Hochmuth and Hanlon, 1995), denitrification, and volatilization (Cockx and Simonne, 2003; Hofman and Van Cleemput, 2001). On a global scale, the recovery of fertilizer $\mathrm{N}$ in crop production is $\approx 50 \%$ (Eickhout et al., 2006). Movement of fertilizer inputs, especially $\mathrm{N}$, and buildup of phosphorus $(\mathrm{P})$ in the environment can adversely affect natural ecosystems and the water resources they depend on (Mitsch and Gosselink, 2000). As a result, farmers are under pressure to reduce or eliminate nutrient-laden water discharges to the environment (Neal et al., 1996, Tyson et al., 1996;
U.S. Environmental Protection Agency, 2003).

Similar environmental issues are present in intensive recirculating aquaculture systems because they maintain system water quality in part by discharging effluent and replacing it with fresh water at $5 \%$ to $10 \%$ of recirculating water volume per day (Timmons et al., 2002). Concentrations of organic matter, inorganic $\mathrm{N}$, and $\mathrm{P}$ concentration in the wastewater usually require in-system or post-discharge treatment of effluents (Gutierrez-Wing and Malone, 2006; Shnel et al., 2002). Nutrient uptake by plants is one of the most widely recognized biological processes for contaminant removal in wastewater treatment wetlands (Debusk, 1999; Mitsch and Gosselink, 2000). Ammonium-N removal efficiencies of $86 \%$ to $98 \%$ were reported from a constructed wetlands system receiving aquaculture wastewater (Lin et al., 2002). Phytoremediation of aquaculture wastewater by integration with hydroponic production is considered a potentially profitable alternative to the current expensive treatment options (Adler et al., 1996, 2000; Ghaly et al., 2005). Aquaculture wastewater cleanup cost abatement alone can be a major factor in integrating hydroponic and aquaculture systems (Adler, 2001; Adler et al., 2000).

In water, $\mathrm{NH}_{3}$ exists in two forms, which together are called the total ammonia nitrogen [TAN (FrancisFloyd et al., 2009)]. The equilibrium reaction is (Campbell and Reese, 2002)

$$
\mathrm{NH}_{4}{ }^{+} \leftrightarrow \mathrm{NH}_{3}+\mathrm{H}^{+} .
$$

Water temperature and $\mathrm{pH}$ will affect the percentage of each compound in 
the TAN equilibrium. For example, at $28^{\circ} \mathrm{C}$, the percent of $\mathrm{NH}_{3}$ increases by nearly a factor of 10 for each 1.0 increase in $\mathrm{pH}$ and is $0.2 \%, 2 \%$, and $18 \%$ of the TAN for $\mathrm{pH} 6.5,7.5$, and 8.5 , respectively (Francis-Floyd et al., 2009).

In aquaculture, the generation of $\mathrm{NH}_{3}-\mathrm{N}$ in recirculating water through fish waste deposition is based on the fish feeding rate:

$$
\mathrm{PTAN}=\frac{F \times \mathrm{PC} \times 0.092}{T},
$$

where $F$ is feed weight, PC is percent protein content of the feed, $T$ is time $=$ $1 \mathrm{~d}$.

Thus, $1 \mathrm{~kg}$ of fish feed with $30 \%$ protein will produce $27.6 \mathrm{~g}$ of $\mathrm{N}$ in $1 \mathrm{~d}$ (Timmons et al., 2002). As plants take up $\mathrm{NH}_{4}{ }^{+}$, some of the $\mathrm{NH}_{3}$ is converted to $\mathrm{NH}_{4}{ }^{+}$to maintain equilibrium (Fig. 1). The net result is that the amount of $\mathrm{NH}_{3}$ decreases. Most of the plant uptake of $\mathrm{N}$ will be in the $\mathrm{NO}_{3}{ }^{-}$form because of the nitrification occurring in system biofilters. Nitrification is the biochemical conversion by nitrifying bacteria of $\mathrm{NH}_{3}$ to $\mathrm{NO}_{3}{ }^{-}$ (Hagopian and Riley, 1998; Madigan et al., 2003; Prosser, 1986) and is a critical component of aquaculture biofilters (Prinsloo et al., 1999). It is a two-step process with $\mathrm{NO}_{3}{ }^{-}$as the result:Primarily nitrosomonas species:

$$
\begin{aligned}
& \mathrm{NH}_{3}+11 / 2 \mathrm{O}_{2} \leftrightarrow \mathrm{NO}_{2}^{-}+\mathrm{H}_{2} \mathrm{O}+\mathrm{H}^{+} \\
& +84 \mathrm{kcal} \mathrm{mol}^{-1} .
\end{aligned}
$$

Primarily nitrobacter species:

$$
\begin{gathered}
\mathrm{NO}_{2}{ }^{-}+1 / 2 \mathrm{O}_{2} \leftrightarrow \mathrm{NO}_{3}{ }^{-} \\
+17.8 \mathrm{kcal} \mathrm{mol}^{-1} .
\end{gathered}
$$

System sizing is an important design consideration for the proper integration of nutrient flow in aquaponics. In hydroponic greenhouse production systems receiving aquaculture wastewater, Adler et al. (1996) found that differences in nutrient removal rates of $\mathrm{NO}_{3}{ }^{-}-\mathrm{N}$ and $\mathrm{P}$ were dependent on plant numbers and effluent flow rate. If plant numbers are high enough, nutrient concentration can decrease to levels that may be too low to sustain the growth of plants. Rakocy et al. (1997) were able to establish a balanced system by maintaining a large plant growing area relative to fish production area in a commercial scale aquaponics system. Rakocy (1999) indicated that sufficient $\mathrm{N}$ is available to plants in lettuce (Lactuca sativa) floating raft systems when correct ratios of fish feed to plant growing area are maintained. In a romaine lettuce/tilapia (Oreochromis niloticus) floating aquaponic system, each square meter of hydroponic growing area removed $0.83 \mathrm{~g}$ of total $\mathrm{N}$ and $0.17 \mathrm{~g}$ of total $\mathrm{P}$ per day. The average feed input per unit plant growing area was found to be $57 \mathrm{~g} \cdot \mathrm{m}^{-2}$ per day for continuous year-round lettuce production (Rakocy, 1997). Estimates of the $\mathrm{N}$ requirements of hydroponic vegetable plants can range from 0.3 to $52 \mathrm{~g}$ of $\mathrm{N}$ per season per lettuce or tomato (Solanum lycopersicum) plant (Keener et al., 2009). A fish waste stream production rate of $90 \mathrm{~g}$ of $\mathrm{N}$ per day would support 4500 lettuce plants (35-d crop) or 507 tomato plants (293-d crop).

Integrating nutrient flows between aquaculture and hydroponic systems turns a waste stream into a crop production asset. Fertilizer costs can range from $5 \%$ to $10 \%$ of total crop production expenses because of the large amount of fossil fuels needed for the manufacture of fertilizer (Hochmuth and Hanlon, 2010). It is possible to produce most of the nutrients needed to grow crops in aquaponic systems through integrated nutrient flows with the initial input being fish feed, although some supplementation with specific plant nutrients such as calcium $\left(\mathrm{Ca}^{2+}\right)$, potassium $(\mathrm{K})$, and iron $(\mathrm{Fe})$ will be required to maximize crop yields (Rakocy et al., 1997). Calcium and $\mathrm{K}$ are used primarily to keep $\mathrm{pH}$ at optimum levels. Aquaponic systems that rely solely on fish waste to supply nutrients for plants have reported low levels of $\mathrm{P}, \mathrm{K}, \mathrm{Fe}$, and manganese (Mn) (Adler et al., 1996) and $\mathrm{P}$, sulfur $(\mathrm{S}), \mathrm{K}$, and Fe (Seawright et al., 1998) in recirculating water. Plants' uptake of $\mathrm{NH}_{4}{ }^{+}$and $\mathrm{NO}_{3}{ }^{-}$as well as other recirculating system nutrients like $\mathrm{P}$ reduces the waste stream in aquaponics and turns an environmental liability into a biologically produced crop production asset.

IMPROVING NUTRIENT USE EFFICIENCY. In soils, nutrients move to the surface of roots by diffusion and bulk flow of the soil solution resulting from transpiration (Taiz and Zeiger, 2006). Concentration gradients can form in the soil solution as nutrients are taken up by the roots and the concentration of nutrients at the root surface is lowered compared with the surrounding area. This can result in a nutrient depletion zone near the root surface. The capacity for continuous growth by roots, however, extends this region of nutrient uptake beyond the depletion zone. Thus, optimum nutrient acquisition by plants in nature depends on the capacity of their root systems not only to absorb nutrients but also to grow into fresh soil.

In hydroponic production using soilless media, the media volume is finite and nutrient depletion can occur and be recovered in the next irrigation event. Nitrogen depletion occurred at lower N (90 to $175 \mathrm{mg} \cdot \mathrm{L}^{-1}$ ) nutrient solution concentrations with intermittent fertigation of cucumber (Cucumis sativus) in rockwool media (Schon and Compton, 1997). Irrigation frequencies that are sufficient to prevent water stress are not necessarily adequate to prevent nutrient depletion except at high $\mathrm{N}$ (225 to $\left.275 \mathrm{mg} \cdot \mathrm{L}^{-1}\right)$ nutrient solution concentrations. Therefore, it seems logical to propose that more frequent flushing of the media even with a lower $\mathrm{N}$ concentration solution could replenish $\mathrm{N}$ in the media, and if the flow was continuous, there would be no appreciable depletion of nutrients in the root zone. This reasoning could apply to all nutrients in the solution. Thus precipitation of certain nutrients at $\mathrm{pH} 8.0$ may not limit the overall nutritional status of the plant, provided continuous recirculation of the nutrient solution through the root/media zone occurs.

Olson (1950) was able to establish that plant nutrients in hydroponic systems were absorbed at a constant rate regardless of concentration, as long as the overall proportion and concentration of nutrients in solution remained nearly the same, and that the nutrient solution was thoroughly mixed and was in constant contact with the roots. Managing hydroponic nutrients in closed systems by the mass balance approach suggests that once the young plant has taken up a sufficient amount of nutrients, concentrations in the solution can be reduced because a finite amount of required nutrients to grow the crop will be either in the plant or in the solution (Bugbee, 2003).

In a 2.5-year continuous multiple cropping pilot project producing lettuce using an integrated aquaponic floating raft system, Rakocy et al. (1997) were able to reduce the amount of $\mathrm{N}$ in the nutrient solution to a concentration 3.5 times less than traditional hydroponic 
solution concentrations. It may be possible to maintain optimum plant yields when lower nutrient solution concentrations are constantly provided to the root system as is the case with recirculating aquaponic systems compared with other production methods. More research is needed to establish these relationships in aquaponics.

REDUCING WATER USE AND DISCHARGE TO THE ENVIRONMENT. Designing agricultural production systems for zero discharge to the environment (zero agricultural discharge system) has the potential to protect groundwater, makes water permitting easier to obtain, and will help maintain the long-term sustainability of agricultural enterprises .

Greenhouse vegetable crops such as tomato, cucumber, and pepper ( $\mathrm{Cap}$ sicum annumm) require as much as 1.9 L of water per plant per day near the mature stage of growth (Hochmuth, 2001a). Given recommended greenhouse plant densities (Marr, 1995), water use would be $\approx 4.5 \mathrm{~L} \cdot \mathrm{m}^{-2}$ per day. Thus a single plant moving through its growth stages may use between 0.5 and 1.9 L of water per day depending on its growth stage and size and the growing season or temperature. Water quality in aquaculture systems is maintained in part by discharging effluent and replacing it with fresh water at $5 \%$ to $10 \%$ of recirculating water volume per day (Timmons et al., 2002). If we assume an average of $1.2 \mathrm{~L}$ of water use per plant per day in a continuous cropping system (with early and late plant stages represented), 100 plants could satisfy the effluent discharge/ freshwater replacement requirements of a recirculating aquaculture tank containing 4380 or $8760 \mathrm{~L}$ (at $10 \%$ or $5 \%$ replacement, respectively) without the need to discharge effluent to the environment as the plant system is absorbing the effluent.

Field-grown vegetable crops, including lettuce, tomato, pepper, and cucumber, have similar crop water requirements based on the reference crop evapotranspiration (Qassim and Ashcroft, 2006). However, plant densities and arrangements in hydroponics are different from field production (Resh, 2004), and sizing the hydroponic subsystem may depend on plant type, density, and arrangement and their effect on water requirements. More research is needed to establish sizing guidelines for various hydroponic crops and aquaculture systems. With the exception of the lettuce/tilapia floating raft aquaponic system worked out by Rakocy (Rakocy, 1997; Rakocy et al., 1997, 2004), no long-term studies have been conducted to provide growers with firm guidelines for system management.

\section{Sustainability challenges}

PH AFFECTS PLANT NUTRIENT AVAILABILITY AND NITRIFICATION RATE. Combining hydroponic and aquaculture systems requires reconciling water quality parameters for the survival and growth of plants, fish, and nitrifying bacteria. However, there are many unanswered questions regarding the optimum water quality and chemistry for the successful culture of these organisms together in aquaponic production. In particular, a dichotomy exists between the optimum $\mathrm{pH}$ for plant nutrient availability in hydroponics $[\mathrm{pH}$ 5.5-6.5 (Hochmuth, 2001a)] and the optimum $\mathrm{pH}$ for nitrifying bacteria activity in aquaculture biofilters $[\mathrm{pH}$ 7.5-9.0 (Hochheimer and Wheaton, 1998); pH 8.5 (Fig. 2)].

Recommended $\mathrm{pH}$ ranges for the nutrient solution irrigation water in greenhouse hydroponic production tends to be slightly acidic $[\mathrm{pH} 5.5-$ 6.5 (Hochmuth, 2001a), pH 5.5-6.0 (Hochmuth, 2001b), pH 5.8-6.4 (Resh, 2004)] to avoid precipitation of $\mathrm{Fe}, \mathrm{Mn}, \mathrm{P}, \mathrm{Ca}$, and $\mathrm{Mg}$ to insoluble and unavailable salts when $\mathrm{pH}>7$. Phosphorus deficiency causing yield reduction in hydroponic tomatoes (Wallihan et al., 1977) and Fe deficiency with dry matter yield reduction in sorghum (Sorghum bicolor) grown in solution culture (Bernardo et al., 1984) occurred when $\mathrm{pH}$ levels were

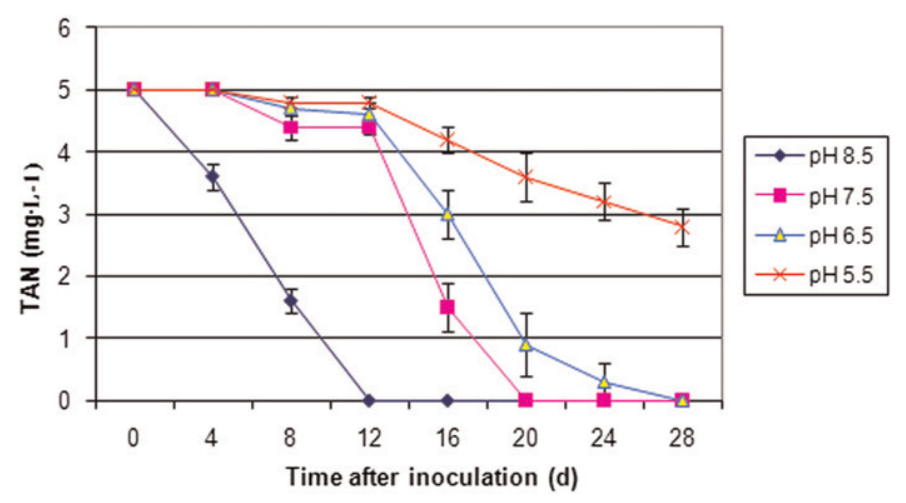

Fig. 2. The effect of recirculating water $\mathrm{pH}$ on total ammonia nitrogen (TAN) loss from tanks with perlite medium trickling biofilters after being inoculated with nitrifying bacteria (Nitrosomonas spp. and Nitrobacter spp.). Error bars represent \pm SE $(\mathbf{n}=8) ; 1 \mathrm{mg} \cdot \mathrm{L}^{-1}=1$ ppm (adapted from Tyson et al., 2004). above 7.0. If aquaponic recirculating water $\mathrm{pH}$ is maintained at levels more optimum for nitrifying bacteria $[\mathrm{pH}$ 7.5-9.0 (Hochheimer and Wheaton, 1998)], plant uptake of certain nutrients may become restricted and thus plant yield may be reduced.

However, research with hydroponic and aquaponic cucumber production suggests that total yields may be maintained at $\mathrm{pH}$ levels above those recommended for the production of plants, even with reduced nutrients in recirculating solutions, when the nutrients constantly bathe the roots (Tyson et al., 2008a, b). When cucumbers were grown at $\mathrm{pH}$ of 5.0, 6.0, 7.0, and 8.0, early cucumber yield was higher at $\mathrm{pH} 5.0$ compared with that at $\mathrm{pH} 8.0$ but total yield was unaffected by $\mathrm{pH}$. Thus, cucumbers in recirculating culture may be maintained at $\mathrm{pH}$ levels more optimum for nitrification ( $\mathrm{pH}$ 7.5-8.0), except during production for early season markets (Tyson et al., 2008b). Research with other hydroponic vegetable crops such as tomato and pepper is needed to determine if $\mathrm{pH}$ ranges can be managed to accommodate nitrification and thus improve the sustainability of aquaponic production.

A biofilter is simply a surface on which nitrifying bacteria can grow. Biofilters used in recirculating aquaculture are of two main types: fixed film (attached growth) and suspended growth (Gutierrez-Wing and Malone, 2006). Biological filtration can take place anywhere in the system where recirculating to which nitrifying bacteria are attachedthis may include tank walls, interior surfaces of pipes, and even plant roots water comes in contact with a surface 
(Rakocy et al., 2006). Most biofiltration in recirculating systems are aerobic, fixed-film biofilters (submerged bed, rotating disk, fluidized bed, and trickling). Of these, the trickling biofilter can also be used as a root growth medium and thus many aquaponic systems use a a trickling, flow-through or intermittent (ebb and flow) biofiltration/plant growth aquaponic subunit (Lennard and Leonard, 2006; McMurtry et al., 1997; Tyson et al., 2008a; Watten and Busch, 1984). Volumetric nitrification TAN generation rates of $\approx 90 \mathrm{~g} \cdot \mathrm{m}^{-3}$ per day of biofilter volume can be expected with trickling filters (Losordo et al., 1999). Tyson et al. (2008a) found that removal of TAN from perlite trickling biofilters was 19,31 , and $80 \mathrm{~g} \cdot \mathrm{m}^{-3}$ per day for system water $\mathrm{pH}$ of $6.0,7.0$, and 8.0, respectively (Fig. 3). Thus, the highest biofiltration occurred at operating system water $\mathrm{pH}$ levels above those currently recommended for hydroponic production.

IMPORTANCE OF BIOFILTRATION TO REDUCE $\mathbf{N H}_{3}$ AND balanCe $\mathbf{N}$ UPTAKE. Except for oxygen, $\mathrm{NH}_{3}$ concentration is the most important water Floyd et al., 2009). Ammonia is the main excretion product from fish and a by-product of uneaten feed. Ammonia is toxic to fish at levels above 0.05 $\mathrm{mg} \cdot \mathrm{L}^{-1}$ (Francis-Floyd et al., 2009). As previously discussed, nitrification is the biological process performed by nitrifying bacteria that reduces $\mathrm{NH}_{3}$ from the water (Gutierrez-Wing and Malone, 2006; Masser, et al., 1999; Prinsloo bench media-filled bed that doubles as quality factor affecting fish (Francis-

et al., 1999). Nitrate, the end product of nitrification, is not toxic to fish except at very high levels [channel catfish (Ictalurus punctatus) 96-h LC50 (lethal concentration at which $50 \%$ of the fish die in $96 \mathrm{~h}$ ) > $6200 \mathrm{mg} \cdot \mathrm{L}^{-1} \mathrm{NO}_{3}-\mathrm{N}$ (Colt and Tchobanoglous, 1976)], although some investigations suggest that prolonged exposure to $200 \mathrm{mg} \cdot \mathrm{L}^{-1}$ $\mathrm{NO}_{3}-\mathrm{N}$ might decrease the immune response of some fish species (Hrubec et al., 1996). Nitrate is the primary source of $\mathrm{N}$ for plants in hydroponic nutrient solutions at concentrations from 50 to $280 \mathrm{mg} \cdot \mathrm{L}^{-1} \mathrm{NO}_{3}-\mathrm{N}$ (Resh, 2004).

The size of aquaculture biofilters should be calculated based on the amount of $\mathrm{NH}_{3}$ added to the system. This is closely related to the feeding rate and efficiency of food utilization (Tetzlaff and Heidinger, 1990). Chapman (2000) puts these aquaculture feed levels for tilapia at $6 \%$ to $15 \%$ of body weight for young fish (fish size $<25 \mathrm{~g}$ ) and $1 \%$ to $3 \%$ of body weight for older fish $(>25 \mathrm{~g}) \cdot \mathrm{NH}_{3}$ is usually not a problem if the biological filters are properly sized for the loading rate and carrying capacity and if adequate water flow through the biofilters is maintained (Fowler et al., 1994). McGee and Cichra (2000) recommend a 3:1 fish tank to biofilter volume ratio as being a more than sufficient size design for aquaculture biofilters. Hochheimer and Wheaton (1998) recommend that the total amount of aquaculture system water should move through the biological filter at least 2-3 times per hour.

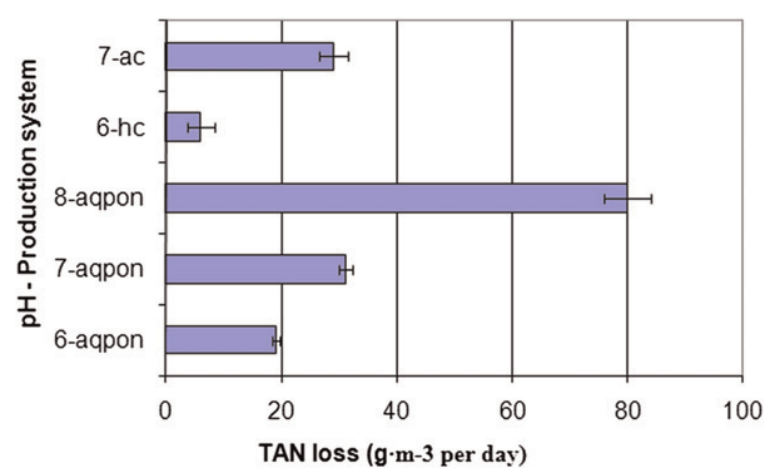

Fig. 3. Total ammonia nitrogen (TAN) loss from recirculating tank water measured at $24 \mathrm{~h}$ after introduction of ammonia $\left(\mathrm{NH}_{3}\right)$. TAN loss is influenced by $\mathrm{pH}$ and production system in an experiment with the following treatments: 6.0-aqpon, 7.0-aqpon, 8.0-aqpon $=$ aquaponic system $\mathrm{pH}$ of 6.0, 7.0, and 8.0, respectively, with plants, fish, and nitrifying bacteria (Nitrosomonas spp. and Nitrobacter spp.); 6.0-hc $=$ pH 6.0 hydroponic control with plants; 7.0-ac $=\mathrm{pH} 7.0$ aquaculture control with fish and nitrifying bacteria. Error bars represent $\pm S E(n=4) ; 1 \mathrm{~g} \cdot \mathrm{m}^{-3}=$ $0.0010 \mathrm{oz} / \mathrm{ft}^{3}$ (adapted from Tyson et al., 2008a).
However, Rakocy et al. (1997) were unable to detect any difference in tilapia growth rate, total weight, or survival between water exchange rates through the biofilter of 0.55 and 1.25 times per hour. Could this difference be the result of nutrients and water uptake by plants in Rakocy's aquaponic system?

Nitrogen, the nutrient required in largest amounts for the optimum (Marschner 2003) production of plants, can be supplied by fish in an aquaponic system (Rakocy et al., 1997). Root uptake by plants of $\mathrm{NH}_{4}{ }^{+}$may be sufficient to reduce reliance on biofilter nitrification for $\mathrm{NH}_{3}$ removal when sufficient plants are available in aquaponic systems (Verhagen et al., 1994). Other research suggests that nitrification plays a more important role in TAN removal than in plants (Tyson et al., 2008a) (Fig. 3). Either way, most plant species are not able to grow optimally with $\mathrm{NH}_{4}{ }^{+}$ as the sole source of $\mathrm{N}$ (Cruz et al., 2006), especially cucumber, a common hydroponically grown crop (Chaverria et al., 2005; Roosta and Schjoerring, 2007). Sufficient nitrification to convert $\approx 75 \%$ of the $\mathrm{NH}_{3}$ to $\mathrm{NO}_{3}{ }^{-}$would be preferred (a ratio of 75:25 of $\mathrm{NO}_{3}{ }^{-}$ to $\mathrm{NH}_{4}{ }^{+}$) because adding some $\mathrm{NH}_{4}{ }^{+}$, compared with nitrate alone as the sole source of $\mathrm{N}$, has been shown to be beneficial to plant growth and yield in hydroponics (Bialczyk et al., 2007; Cockx and Simonne, 2003; Simonne et al., 1992).

Plants can provide a biofiltration role by absorbing $\mathrm{NH}_{4}{ }^{+}$and thus reducing toxic $\mathrm{NH}_{3}$ through the TAN equilibrium (Eq. 1), but only nitrification in the biofilter can provide the dual role of reducing $\mathrm{NH}_{3}$ concentration through oxidation and converting $\mathrm{NH}_{3}$ to $\mathrm{NO}_{3}^{-}$, a necessary form of $\mathrm{N}$ for optimum crop production. More research is needed to investigate biological $\mathrm{N}$ production that minimizes adverse impacts on yields of plants, which may result from maintaining system water quality at levels that optimize nitrification rates.

The DEMAND FOR INNOVATION IN SUSTAINABLE AQUAPONIC SYSTEMS. In 2008, imported fish and shrimp (Penaeus spp.) accounted for $79 \%$ of all fish and shrimp sold domestically (Jerardo, 2008). Despite the known health benefits of consuming fish and vegetables, per capita consumption of fish (fresh plus frozen) is less than $4 \mathrm{lb}$ per year and per capita consumptions 
of fresh vegetables is $92 \mathrm{lb}$ per year or less than one serving a day each (U.S. Department of Agriculture (USDA) ERS, 2010). Increased regulatory constraints that limit wild harvest of seafood to ensure supply over the long term, in addition to federal policies and programs that support increases in per capita consumption of fresh produce, have spurred a renewed interest in aquaculture and aquaponic systems.

The USDA's “Know Your Farmer, Know Your Food" initiative includes 20 grant, loan, and support programs, made possible in part by the 2008 Farm Bill funding increases, that may directly or indirectly influence outcomes related to public health and the economic welfare of communities through improvements to farms and food systems (Hardesty, 2010). Sources of technological advancements in agricultural systems typically originate from land grant universities' research and innovations of farm entrepreneurs seeking to improve the efficiency of their own systems. Increasingly, publicprivate partnerships for innovation are nurtured by federal competitive funding. A search of the term "aquaponics" in the USDA Current Research Information System revealed that only $\$ 7$ million in federal funds has been awarded to aquaponics projects since 2000 , and many of these programs include public-private partnerships. Clearly, there are many more improvements to be made to these systems, and there is ample opportunity for research and outreach programs from federal research dollars.

Because of public concerns over energy and water use in agriculture, technological and cultural innovations that reduce the ecological footprint of aquaponic systems will be welcomed. Engineering advancements to reduce overall water use, application of alternative energy sources to power pumps and heaters, and increased precision of temperature and humidity through improved structure design and controls will improve efficiency (Conservation Fund's Freshwater Institute, 1997; Lennard and Leonard, 2006; Losordo and Westerman, 2007).

The energy costs related to the production, processing, and distribution of fish feed are unknown, but expected to be significant. When stocking rates are high, fish are provided feed that generally is high in protein supplied by soybean meal, cottonseed meal, and peanut meal (Naylor et al., 2000). Innovation is needed to develop alternative feed sources that are nutritious, affordable, and locally available. Economic data to guide decisions on adoption of new technology and cultural practices are needed.

Traditionally, farming has been a rural enterprise, but due in part to farmland loss and increased populations, agriculture is increasingly found in urban-influenced counties (American Farmland Trust, 2009). These counties currently provide $78 \%$ of U.S. vegetables and melons (Cucurbitaceae). Systems that are scalable and affordable are likely to be readily adoptable in a variety of agricultural settings including urban farming applications. Fish processors with USDA certification are needed in proximity to suppliers and end-users to facilitate sales. Several species of fish can be produced in aquaponic systems, but market research is needed to determine consumer preferences and consumers' willingness to pay for the true cost of the product. Profitable farming systems are especially important for maintaining farming enterprises in peri-urban areas to ensure sufficient domestic food supply (Council for Agricultural Science and Technology, 2010). Current and pending food safety regulations may limit farmer access to indirect market channels such as mass market retailers and farm-to-school networks. To capture these markets, aquaponic farmers should take the initiative to insure they receive the proper training to develop farm food safety plans and are prepared to comply with third party certification programs and audits.

\section{Conclusion}

In aquaponics, the grower needs to understand the fish system and the crop system and must integrate between them. Aquaponics can be a sustainable agricultural production system. Most plant nutrients can be derived from fish feed through fish digestion/ excretion and biofilter nitrification, thus integrating nutrient flow. Plants can act as biofilters and take up system effluent that would otherwise be discharged to the environment. The difficulty in finding a median growing environment among plants, fish, and nitrifying bacteria culture in aquaponics has resulted in less integration of the systems than would be ideal for maximizing space and infrastructure, thus reducing the potential overall adaptability and profitability of aquaponics. We know that aquaponic systems management has been established for the lettuce/tilapia floating raft system, but more long-term research/demonstrations should be conducted on sizing and managing other aquaponic crop/fish system combinations to reduce adoption uncertainty.

Even though plants provide a beneficial biofiltration role, nitrification is very important for the maintenance of water quality and conversion of potentially harmful $\mathrm{NH}_{3}$ to $\mathrm{NO}_{3}{ }^{-}$. We suggest system sustainability could be improved by maintaining water $\mathrm{pH}$ nearer the optimum for nitrification ( $\mathrm{pH} 7.5-8.0)$ rather than the optimum for plant production ( $\mathrm{pH}$ 5.5-6.5), provided plant yields are not reduced. Aquaponic cucumbers were grown with recirculating water $\mathrm{pH}$ ranging from 6.0 to 8.0 , thus increasing system nitrification rate and production of biologically produced $\mathrm{NO}_{3}{ }^{-}-\mathrm{N}$ at the higher $\mathrm{pH}$ levels, without affecting total yield. Other hydroponic vegetable crop species should be tested under aquaponic conditions to determine how crop yields are affected by operating at $\mathrm{pH}$ levels more suitable for biofilter nitrification to maximize longterm sustainability.

Balancing the aquaponic system environment for the optimum growth of three organisms will be an on-going subject of research and refinement. Further aquaponic systems' adoption will require more public and private resources to close many knowledge gaps in properly managing these systems and successfully marketing their products to the public.

\section{Literature cited}

Adler, P. 2001. Overview of economic evaluation of phosphorus removal by plants. Aquaponics J. 5:15-18.

Adler, P.R., J.K. Harper, F. Takeda, E.D. Wade, and S.T. Summerfelt. 2000. Economic evaluation of hydroponics and other treatment options for phosphorus removal in aquaculture effluent. HortScience 35: 993-999.

Adler, P.R., F. Takeda, D.M. Glenn, and S.T. Summerfelt. 1996. Utilizing byproducts to enhance aquaculture sustainability. World Aquaculture 27:2426.

American Farmland Trust. 2009. Farming on the Edge Report. 21 June 2010. <http://www.farmland.org/resources/ fote/default.asp> 
Bernardo, L.M., R.B. Clark, and J.W. Maranville. 1984. Nitrate/ammonium ratio effects on nutrient solution $\mathrm{pH}$, dry matter yield, and nitrogen uptake of sorghum. J. Plant Nutr. 7:1389-1400

Bialczyk, J., Z. Lechowski, D. Dziga, and E. Mej. 2007. Fruit yield of tomato cultivated on media with bicarbonate and nitrate/ammonium as the nitrogen source. J. Plant Nutr. 30:149-161.

Bugbee, B. 2003. Nutrient management in recirculating hydroponic culture. Acta Hort. 648:99-112.

Campbell, N.A. and J.B. Reese. 2002. Biology, 6th ed. Pearson Education, San Francisco, CA.

Chapman, F.A. 2000. Culture of hybrid tilapia: A reference profile. Univ. Florida, Dept. Fisheries Aquatic Sci., Florida Coop. Ext. Serv. Cir. 1051, 27 Oct. 2010. $<$ http://edis.ifas.ufl.edu/FA012>

Chaverria, C.J., G. Hochmuth, R. Hochmuth, and S. Sargent. 2005. Fruit yield, size, and color responses of two greenhouse cucumber types to nitrogen fertilization in perlite soilless culture. HortTechnology 15:565-571.

Cockx, E. and E.H. Simonne. 2003. Reduction of the impact of fertilization and irrigation on processes in the nitrogen cycle in vegetable fields with BMPs. Univ. Florida, Hort. Sci. Dept., Florida Coop. Ext. Serv. HS948, 27 Oct. 2010. <http://edis.ifas.ufl.edu/HS20l>.

Colt, J.E. and G. Tchobanoglous. 1976. Evaluation of the short-term toxicity of nitrogenous compounds to channel catfish, Ictalurus punctatus. Aquaculture 8:209-224.

Conservation Fund's Freshwater Institute. 1997. The Freshwater Institute natural gas powered aquaponic system design manual. Conservation Fund's Freshwater Inst., Shepherdstown, WV.

Council for Agricultural Science and Technology. 2010. Agricultural productivity strategies for the future: Addressing US and global challenges. Issue Paper No. 45. Council for Agricultural Sci. Technol., Ames, IA.

Cruz, C.A., F.M. Bio, M.D. DominguezValdivia, P.M. Aparicio-Tejo, C. Lamsfus, and M.A. Martins-Loucao. 2006. How does glutamine synthetase activity determine plant tolerance to ammonium? Planta 223:1068-1080.

Debusk, W.F. 1999. Wastewater treatment wetlands: Contaminant removal processes. Univ. Florida, Soil Water Sci. Fact Sheet SL 155.

Diver, S. and L. Rinehart. 2010. AquaponicsIntegration of hydroponics and aquacul- ture. Apropriate technology transfer for rural areas: Horticulture systems guide, 27 Oct. 2010. <http://attra.ncat.org/ attra-pub/aquaponic.html>.

Eickhout, B., A.F. Bouwman, and H. van Zeijts. 2006. The role of nitrogen in world food production and environmental sustainability. Agr. Ecosyst. Environ. 116:4-14.

Fedoroff, N.V., D.S. Battisti, R.N. Beachy, P.J.M. Cooper, D.A. Fischhoff, C.N. Hodges, V.C. Knauf, D. Lobell, B.J. Mazur, D. Molden, M.P. Reynolds, P.C. Ronald, M.W. Rosegrant, P.A. Sanchez, A. Vonshak, and J.K. Zhu. 2010. Radically rethinking agriculture for the 21 st Century. Science 327:833-834.

Fowler, P., D. Baird, R. Bucklin, S. Yerlan, C. Watson, and F. Chapman. 1994. Microcontrollers in recirculating aquaculture systems. Univ. Florida, Energy Ext. Serv. EES-326.

Francis-Floyd, R., C. Watson, D. Petty, and D.B. Pouder. 2009. Ammonia in aquatic systems. Univ. Florida, Dept. Fisheries Aquatic Sci., Florida Coop. Ext. Serv. FA-16, 27 Oct. 2010. <http://edis.ifas.ufl. edu/FA031 $>$.

Ghaly, A.E., M. Kamal, and N.S. Mahmoud. 2005. Phytoremediation of aquaculture wastewater for water recycling and production of fish feed. Environ. Intl. 31:1-13.

Gold, M.V. 1999. Sustainable agriculture: Definitions and terms. 27 Oct. 2010. <http://www.nal.usda.gov/afsic/ AFSIC_pubs/srb9902.htm>.

Gutierrez-Wing, M. and R.F. Malone. 2006. Biological filters in aquaculture: Trends and research directions for freshwater and marine applications. Aquacult. Eng. 34:163-171.

Hagopian, D.S. and J.G. Riley. 1998. A closer look at the bacteriology of nitrification. Aquacult. Eng. 18:223-244.

Hardesty, S.D. 2010. Do government policies grow local food? Choices 25(1):28-31. 15 June 2010. <http://www.choicesmagazine. org $/$ magazine $/$ article. php?article $=113>$.

Hochheimer, J.N. and F. Wheaton. 1998. Biological filters: Trickling and RBC design. Proc. 2nd Intl. Conf. Recirculating Aquaculture. p. 291-318.

Hochmuth, G. 2000. Nitrogen management practices for vegetable production in Florida. Univ. Florida, Hort. Sci. Dept., Florida Coop. Ext. Serv. Cir. 222.

Hochmuth, G.J. 2001a. Fertilizer management for greenhouse vegetables, Florida greenhouse vegetable production handbook, Vol. 3. Univ. Florida, Hort. Sci. Dept., Florida Coop. Ext. Serv. HS787. 27 Oct. 2010. <http://edis.ifas.ufl.edu/ CV265>.
Hochmuth, G.J. 2001b. Greenhouse cucumber production: Florida greenhouse vegetable production handbook, Vol. 3. Univ. Florida, Hort. Sci. Dept., Florida Coop. Ext. Serv. HS790. 27 Oct. 2010. <http://edis.ifas.ufl.edu/cv268>.

Hochmuth, G.J. and E.A. Hanlon. 1995. IFAS standard fertilization recommendations for vegetable crops. Univ. Florida, Hort. Sci. Dept., Florida Coop. Ext. Serv. Cir. 1152.

Hochmuth, G.J. and E.A. Hanlon. 2010. Commercial vegetable fertilization principles. Univ. Florida, Soil Water Sci. Dept., Florida Coop. Ext. Serv. SL319. 14 May 2010. <http://edis.ifas.ufl.edu/cv009>.

Hofman, G. and O. Van Cleemput. 2001. Gaseous N losses from field crops. Acta Hort. 563:155-162.

Hrubec, T.C., S.A. Smith, and J.L. Robertson. 1996. Nitrate toxicity: A potential problem of recirculating systems. Successes and failures in commercial recirculating aquaculture. Aquacultural Eng. Soc. Proc. II, Natural Resource Agr. Eng. Serv. Vol. 1. p. $41-48$.

Jensen, M.H. 1997. Hydroponics. HortScience 32:1018-1021.

Jerardo, A. 2008. What share of US consumed food is imported? Amber Waves, Feb. 2008. 2 June 2010. <http://www. ers.usda.gov/AmberWaves/February08/ DataFeature $/>$.

Keener, H., B. Fausey, B. Bauerle, P. Ling, R. Hansen, and C. Draper. 2009. Ohio State University Hydroponic Crop Program. Wooster, OH. 29 Dec. 2009. <http://www.oardc.ohio-state.edu/ hydroponics/drade/index.php $>$.

Lennard, W.A. and B.V. Leonard. 2006. A comparison of three different hydroponic sub-systems (gravel bed, floating and nutrient film technique) in an aquaponic test system. Aquacult. Intl. 14:539-550.

Lim, C. and C.D. Webster. 2006. Tilapia: Biology, culture, and nutrition. Food Products Press, Binghamton, NY.

Lin, Y.F., S.R. Jing, D.Y. Lee, and T.W. Wang. 2002. Nutrient removal from aquaculture wastewater using a constructed wetlands system. Aquaculture 209:169-184.

Losordo, T.M. and P.W. Westerman. 2007. An analysis of biological, economic, and engineering factors affecting the cost of fish production in recirculating aquaculture systems. J. World Aquacult. Soc. 25:193-203.

Losordo, T.M., M.P. Masser, and J.E. Rakocy. 1999. Recirculating aquaculture tank production systems: A review of component options. Southern Reg. Aquaculture Ctr. Pub. No. 453. 
Madigan, M.T., J.M. Martinko, and J. Parker. 2003. Brock biology of microorganisms, 10th ed. Pearson Education, Upper Saddle River, NJ.

Marr, C.W. 1995. Commercial greenhouse production: Greenhouse cucumbers. Kansas State Univ., Agr. Expt. Sta., Coop. Ext. Serv. MF-2075.

Marschner, H. 2003. Mineral nutrition of higher plants. Academic Press, San Diego, CA.

Masser, M.P., J. Rakocy, and T.M. Losordo. 1999. Recirculating aquaculture tank production systems: Management of recirculating systems. Southern Reg. Aquaculture Ctr. Pub. No. 452.

McGee, M. and C. Cichra. 2000. Principles of water recirculation and filtration in aquaculture. Univ. Florida, Dept. Fisheries Aquatic Sci., Florida Coop. Ext. Serv. FA-12.

McMurtry, M.R., D.C. Sanders, J.D. Cure, and R.G. Hodson. 1997. Effects of biofilter/ culture tank volume ratios on productivity of a recirculating fish/vegetable co-culture system. J. Appl. Aquacult. 7:33-51.

McMurtry, M.R., P.V. Nelson, D.C. Sanders, and L. Hodges. 1990. Sand culture of vegetables using recirculated aquacultural effluents. Appl. Agr. Res. 5: $280-284$

Mitsch, W.J. and J.G. Gosselink. 2000. Wetlands, 3rd ed. Wiley, New York.

Naylor, R.L., R.J. Goldurg, J.H. Primavera, N. Kautsky, M.C.M. Beveridge, J. Clay, C. Folkes, J. Lubchenco, H. Mooney, and M. Troell. 2000. Effect of aquaculture on world fish supplies. Nature 405:1017-1024.

Neal, C.A., R.V. Tyson, E.A. Hanlon, J.M. White, and S. Cox. 1996. Reducing nutrient applications for vegetable production in the Lake Apopka basin. Proc. Florida State Hort. Soc. 109:156-159.

Nelson, R.L. 2007. Ten aquaponic systems around the world. Aquaponics J. 46:8-12.

Olson, C. 1950. The significance of concentration on the rate of ion absorption by higher plants in water culture. Physiol. Plant. 3:152-164.

Prinsloo, J.F., W. Roets, J. Theron, L.C. Hoffman, and H.J. Schoonbee. 1999. Changes in some water quality conditions in recycling water using three types of biofiltration systems during the production of the sharptooth catfish Clarias gariepinus (Burchell). Part 1. Relative efficiency in the breakdown of nitrogenous wastes by the different biofiltration units. Water S.A. 25: 239-252.

Prosser, J.I. 1986. Nitrification. Soc. Microbiol. Special Publ., Vol. 20. IRL Press, Oxford, UK.
Qassim, A. and B. Ashcroft. 2006. Estimating vegetable crop water use with moistureaccounting method. State of Victoria Agr. Notes AG 1192. 5 Nov. 2010. <http:// www.dpi.vic.gov.au/DPI/nreninf.nsf/v/ BEF9D450B258DA22CA2574240019856 A/\$file/Estimating_Vegetable_Crop_ Water_use_with_Moisture_Accounting _ Method.pdf $>$.

Rakocy, J.E. 1997. Integrating tilapia culture with vegetable hydroponics in recirculating systems, p. 163-184. In: B.A. Costa-Pierce and J.E. Rakocy (eds.). Tilapia aquaculture in the Americas. Vol. 1. World Aquaculture Soc., Baton Rouge, LA.

Rakocy, J.E. 1999. Aquaculture engineering: The status of aquaponics, Part 1 . Aquacult. Mag. 25:83-88

Rakocy, J.E., D.S. Bailey, K.A. Shultz, and W.M. Cole. 1997. Evaluation of a commercial-scale aquaponic unit for the production of tilapia and lettuce. 4th Intl. Symp. on Tilapia in Aquacult. 1:357-372.

Rakocy, J.E., D.S. Bailey, R.C. Schultz, and E.S. Thoman. 2004. Update on tilapia and vegetable production in the UVI aquaponic system. 27 Oct. 2010. <http://ag.arizona. edu/azaqua/ista/ista6/ista6web/pdf/ 676.pdf>.

Rakocy, J.E., T.M. Losordo, and M.P. Masser. 2006. Recirculating aquaculture tank production systems: AquaponicsIntegrating fish and plant culture. Southern Reg. Aquaculture Ctr. Pub. No. 454.

Resh, H.M. 2004. Hydroponic food production, 6th ed. New Concept Press, Mahwah, NJ.

Roosta, H.R. and J.K. Schjoerring. 2007. Effects of ammonium toxicity on nitrogen metabolism and elemental profile of cucumber plants. J. Plant Nutr. 30:1933-1951.

Schon, M.K. and M.P. Compton. 1997. Nitrogen and phosphorus requirements for rockwool grown cucumbers trained with a double-stem method. HortTechnology 7: 33-38.

Seawright, D.E., R.R. Stickney, and R.B. Walker. 1998. Nutrient dynamics in integrated aquaculture-hydroponics systems. Aquaculture 160:215-237.

Shnel, N., Y. Barak, T. Ezer, Z. Dafni, and J. van Rijn. 2002. Design and performance of a zero-discharge tilapia recirculating system. Aquacult. Eng. 26:191-203.

Simonne, E.H., H.A. Mills, and D.A. Smittle. 1992. Ammonium reduces growth, fruit yield and fruit quality of watermelon. J. Plant Nutr. 15:2727-2741.

Smither-Kopperl, M.L. and D.J. Cantliffe. 2004. Protected agriculture as a methyl bromide alternative? Current reality and future promise. Proc. Florida State Hort. Soc. 117:21-27.

Taiz, L. and E. Zeiger. 2006. Plant physiology. 4th ed. Sinauer, Sunderland, MA.

Tetzlaff, B.L. and R.C. Heidinger. 1990. Basic principles of biofiltration and system design. Southern Illinois Univ. Carbondale, Fisheries Illinois Aquaculture Ctr. Bul. 9.

Timmons, M.B., J.M. Ebeling, F.W. Wheaton, S.T. Summerfelt, and B.J. Vinci. 2002. Recirculating aquaculture systems. 2nd ed. Northeastern Reg. Aquaculture Ctr. Pub. No. 01-002.

Tyson, R.V., C.A. Neal, and L.I. Morrell. 1996. Buyout plan for Zellwood area vegetable farms. Citrus Veg. Mag. Aug. 1996:45.

Tyson, R.V., E.H. Simonne, D.D. Treadwell, J.M. White, and A. Simonne. 2008a. Reconciling $\mathrm{pH}$ for ammonia biofiltration and cucumber yield in a recirculating aquaponic system with perlite biofilters. HortScience 43:719-724.

Tyson, R.V., E.H. Simonne, D.D. Treadwell, M. Davis, and J.M. White. 2008b. Effect of water $\mathrm{pH}$ on yield and nutritional status of cucumber grown in recirculating hydroponics. J. Plant Nutr. 31:2018-2030.

Tyson, R.V., E.H. Simonne, J.M. White, and E.M. Lamb. 2004. Reconciling water quality parameters impacting nitrification in aquaponics: The $\mathrm{pH}$ levels. Proc. Florida State Hort. Soc. 117:79-83.

U.S. Department of Agriculture ERS. 2010. Data sets: Loss-adjusted food availability spreadsheets. 2 June 2010. <http://www/ers/usda.gov/Data/Food Consumption/FoodGuideSpreadsheets. htm>.

U.S. Environmental Protection Agency. 2003. Phosphorus reduction in the Everglades. IN71. Nonpoint Source NewsNotes, 27 Oct. 2010. <http://water.epa. gov/aboutow/upload/7lissue.pdf $>$.

Verhagen, F.J.M., P.E.G. Hageman, J.W. Woldendorp, and H.J. Laanbroek. 1994. Competition for ammonium between nitrifying bacteria and plant roots in soil pots: Effects of grazing flagellates and fertilization. Soil Biol. Biochem. 26:89-96.

Wallihan, E.F., R.G. Sharpless, and W.L. Printy. 1977. Effect of $\mathrm{pH}$ on yield and leaf composition of hydroponic tomato. HortScience 12:316-317.

Watten, B.J. and R.L. Busch. 1984. Tropical production of tilapia (Sarotherodon aurea) and tomatoes (Lycopersicon esculentum) in a small-scale recirculation water system. Aquaculture 41:271-283. 